\title{
Photodynamic Inactivation of Bladder Cancer Cells (MGH-U1) Sensitized with Acridine Orange and Irradiated by Argon Laser
}

\author{
Satoru Ishikawa, Ryosuke Nemoto, Shouri Kanoh, \\ Katsumi Kobayashi* and Shozo Ishizaka* \\ Department of Urology, Institute of Clinical Medicine \\ and * Institute of Biological Sciences, University of \\ Tsukuba, Ibaraki 305
}

Ishikawa, S., Nemoto, R., Kanoh, S., Kobayashi, K. and Ishizaka, S. Photodynamic Inactivation of Bladder Cancer Cells (MGH-U1) Sensitized with Acridine Orange and Irradiated by Argon Laser. Tohoku J. exp. Med., 1984,144 (3), 265-271 Photodynamic inactivation of bladder cancer cells (MGH-U1) was investigated in order to apply laser therapy to the treatment of bladder cancer. After stained with acridine orange $(\mathrm{AO})$, the material cells were irradiated with argon laser. After $24 \mathrm{hr}$ incubation the survival was counted with a hemocytometer. The number of stained cells showed a less than $5 \%$ decrease and the number of irradiated (for $15 \mathrm{~min}$ ) unstained cells showed no decrease compared with untreated cells. Participation of singlet oxygen process in inactivation of MGH-Ul cells was confirmed by the use of $\mathrm{D}_{2} \mathrm{O}$ and $\mathrm{NaN}_{3}$. The result shows that argon laser at the low intensity and with short irradiation time has a sufficient cytocydal effect, suggesting the usefulness of photodyamic inactivation of argon laser with topical use of acridine orange in the treatment of bladder cancer. argon laser - photodynamic inactivation; bladder cancer cells; acridine orange;

It is known that admistration of photosensitizing dyes can result in retardation of tumor growth (Lewis and Goland 1948). Further, Tomson et al. (1974) reported the photodestruction of mouse epithelial tumors after administration of oral acridine orange and argon laser. Recently, Dougherty et al. (1978) reported the photoradiation therapy for the treatment of human malignant tumors by using a hematoporphyrin derivative and red light. Kelly et al. (1975) suggested that photodynamic therapy might be applicable to the treatment of superficial transitional carcinoma of the bladder implanted in mice. On the other hand, Ito and Kobayashi (1974) and Kobayashi and Ito (1976) reported the participation of singlet oxygen molecules in the photodynamic inactivation of yeast cells. In order to apply the argon laser irradiation sensitized with photosensitizing dyes to 
clinical use, we have examined the clinical applicability and the participation of singlet oxygen in the photodynamic inactivation, using cultured bladder cancer cells.

\section{Materials and Methods}

Preparation of cells

The MGH-Ul cell line, established from human bladder cancer (Kato et al. 1977, 1978), was used in the present experiments. Cells were cultured in square culture bottles with DM-160 medium (Kyokuto Co., Tokyo) containing 20\% fetal calf serum (Gibco Co., N.Y., USA) at $37^{\circ} \mathrm{C}$ in a $\mathrm{CO}_{2}$ incubator.

Sensitization and treatment with $\mathrm{D}_{2} \mathrm{O}$ and $\mathrm{N}_{3}{ }^{-}$

Cells were stained with acridine orange (Wako Chemicals, Osaka) for sensitization. In the staining, stock solution of acridine orange $(\mathrm{AO})$ was prepared by dissolving $\mathrm{AO}$ in standard saline at a concentration of $\mathrm{OD}_{492}=20\left(3.5 \times 10^{-4} \mathrm{M}\right)$. Sample cells $\left(1 \times 10^{6} / \mathrm{ml}\right)$ were stained for 20 min with $\mathrm{AO}$ solution at a final concentration of $\mathrm{OD}_{492}=1.0\left(1.75 \times 10^{-5}\right.$ $\mathrm{M}$ ), using the stock solution diluted with phosphate-buffered saline ( $\mathrm{PBS}, \mathrm{NaCl} 8 \mathrm{~g} /$ liter, $\mathrm{Na}_{2} \mathrm{HPO}_{4} 1.15 \mathrm{~g} /$ liter, $\mathrm{NaH}_{2} \mathrm{PO}_{4} 0.2 \mathrm{~g} /$ liter, $\mathrm{pH}$ 7.40-7.45).

In addition, cells were treated with deuterated medium and azide ion to examine the participation of the singlet oxygen process. In one treatment, the buffer was prepared with deuterium oxide $\left(\mathrm{D}_{2} \mathrm{O}, 99.8\right.$ atom $\%$, Aldrich Chemical Co., Milwaukee, USA) as a solvent in place of $\mathrm{H}_{2} \mathrm{O} 15 \mathrm{~min}$ prior to laser irradiation. In the other treatment, various amounts of sodium azide $\left(\mathrm{NaN}_{3}\right.$, Wako Chemicals, Osaka) were added to give the indicated final concentration 15 min prior to irradiation.

Irradiation with argon laser

Almost all cell populations were irradiated by argon laser (Nippon Electric Co., Tokyo) under the conditions as follows: The wave length of laser was $496.5 \mathrm{~nm}$ and the intensity at the sample position was about $4.0 \mathrm{~mW} / \mathrm{cm}^{2}$. The laser beam was expanded to $3 \mathrm{~cm}$ in diameter with a slit and two convex lenses.

\section{Determination of survival}

Treated cells with AO and laser were washed four times with PBS and resuspended in medium. All treatments, including sensitization, irradiation and washing were carried out at $16^{\circ} \mathrm{C}$ in a dark room for about $2 \mathrm{hr}$. After $24 \mathrm{hr}$ incubation in a $\mathrm{CO}_{2}$ incubator, cells were removed with a solution of EDTA $(0.02 \%)$ and trypsin $(0.1 \%)$, and living cell numbers were counted with a hemocytometer after staining with trypan blue. The experiments were run in triplicate.

\section{Controls}

Unirradiated cells were taken as controls for inactivation. They were stained with AO, kept in the same room and washed in the same way. The number of stained cells showed a less than $5 \%$ decrease compared with untreated cells.

In the experiment which examined the effect of $\mathrm{AO}$ concentration, the cells similarly irradiated but without staining were taken as controls. The number of irradiated (for 15 $\min$ ) cells without staining showed a less than $1 \%$ decrease compared with untreated cells.

\section{RESUlts}

\section{Relationship between survival and exposure time}

The relationship between survival and exposure time at a fixed concentration 


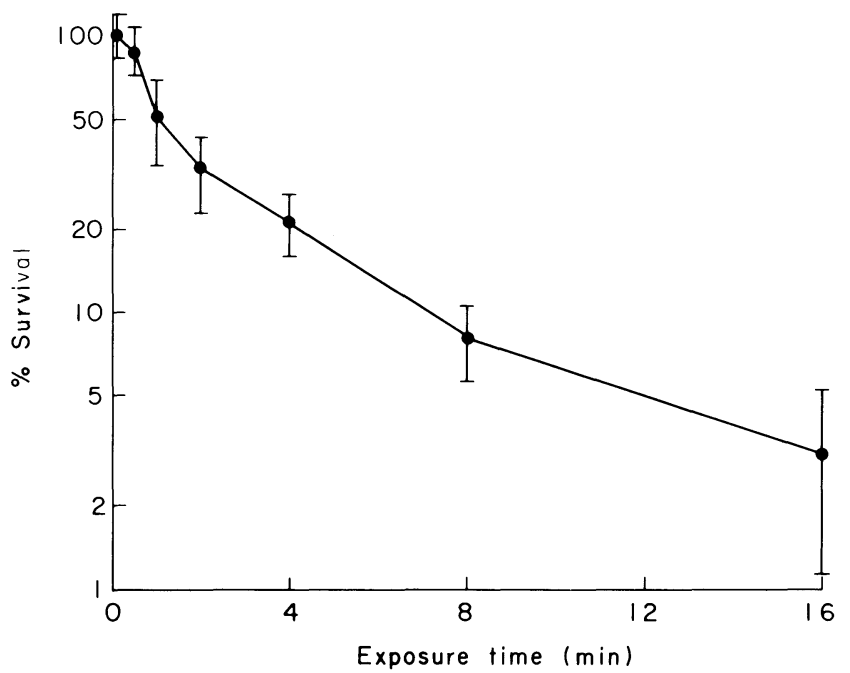

Fig. 1. Relationship between survival and exposure time. MGH-U1 cells, sensitized with AO at a concentration of $1.75 \times 10^{-5} \mathrm{M}$, were irradiated by argon laser. Living cell number was determined $24 \mathrm{hr}$ after irradiation and the percent survival curve was obtained by comparing the living cell number with that of unirradiated cells. Dots are means and the vertical bars indicate the standard deviation.

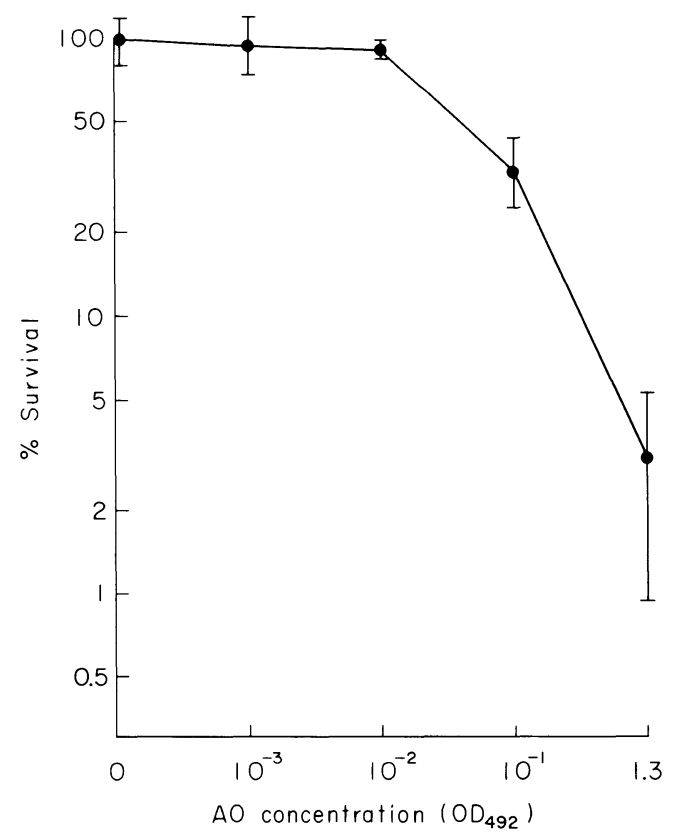

Fig. 2. Relationship between survival and AO concentration. MGH-U1 cells were irradiated by argon laser for $15 \mathrm{~min}$. The percent survival curve was obtained by comparing the living cell number with that of unstained cells. Dots are means and the vertical bars indicate the standard deviation. 
of $\mathrm{AO}\left(\mathrm{OD}_{492}=1.0\right)$, is shown in Fig. 1. In this survival curve, $37 \%$ survival was at 1.5 min exposure. While there was a small shoulder peak in the curve, the survival decreased almost exponentially.

\section{Relationship between survival and $A O$ concentration}

The relationship between survival and AO concentration at 15 min laser exposure is shown in Fig. 2. The decrease in survival curve was remarkable when the $\mathrm{OD}_{492}$ of $\mathrm{AO}$ was over $10^{-2}$, and the concentration of $37 \%$ survival was at about $\mathrm{OD}_{492}=0.1$.

\section{Enhancement by $\mathrm{D}_{2} \mathrm{O}$}

Photodynamic inactivation of cells was enhanced by the replacement of $\mathrm{H}_{2} \mathrm{O}$ with $\mathrm{D}_{2} \mathrm{O}$. The result is shown in Fig. 3 . At 8 min exposure, the difference in survival under the two conditions was highly significant $(p<0.001)$.

\section{Protection by the presence of $\mathrm{N}_{3}{ }^{-}$during irradiation}

The survival decreased in the presence of $\mathrm{NaN}_{3}$ during irradiation, as azide ion is known to have cytocydal action as a metabolic inhibitor (Table 1). When $\mathrm{NaN}_{3}$ was added at a higher concentration, the number of living cell decreased. On the other hand, when $\mathrm{NaN}_{3}$ was added at a higher concentration to $\mathrm{AO}$ staining cells, the number of living cells after irradiation increased. To exclude

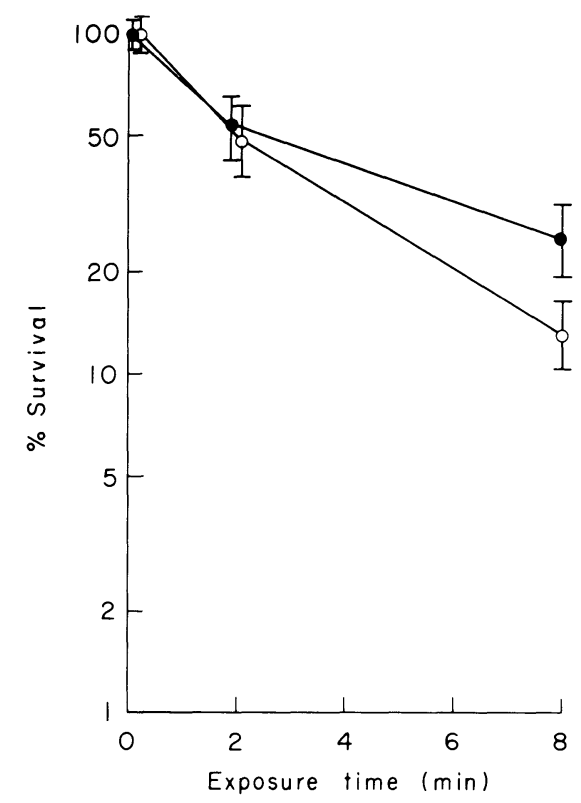

Fig. 3. Effects of $\mathrm{D}_{2} \mathrm{O}$ on the photosensitized inactivation of MGH-Ul cells. Survival curves ( $\mathrm{O}$ for $\mathrm{D}_{2} \mathrm{O}$ and $\bullet$ for $\mathrm{H}_{2} \mathrm{O}$ ) are shown. Symbols are means and vertical bars indicate the standard deviation. 
TABLE 1. Inhibition effect of azide ion on photodynamic inactivation of cancer cells

\begin{tabular}{ccc}
\hline \multirow{2}{*}{ Concentration of $\mathrm{NaN}_{3}(\mathrm{M})$} & No staining with $\mathrm{AO}$ & Staining with AO \\
\cline { 2 - 3 } & Survival (\%) & Survival (\%) \\
\hline 0 & 100 & $20.8 \pm 5.2$ \\
& & $(20.8)^{*}$ \\
$10^{-3}$ & $94.6 \pm 9.7$ & $51.8 \pm 15$ \\
& & $(54.8)^{*}$ \\
$10^{-2}$ & $82.5 \pm 4.6$ & $60.3 \pm 7.7$ \\
& & $(73.1)^{*}$ \\
\hline
\end{tabular}

Irradiation time of laser was 4 min. Values are given as mean \pm s.D.

* Percentage of stained cells over non-stained cells.

the cytocydal effect of $\mathrm{NaN}_{3}$ as a metabolic inhibitor, percentages of stained cells to non-stained cells were calculated. They were $20.8 \%$ without $\mathrm{NaN}_{3}, 54.8 \%$ with $10^{-3} \mathrm{M} \mathrm{NaN}_{3}$ and $73.1 \%$ with $10^{-2} \mathrm{M} \mathrm{NaN}_{3}$ (Table 1). These figures indicated that $\mathrm{NaN}_{3}$ protected the photodynamic inactivation of MGH-U1 cells. This result confirmed the participation of the singlet oxygen process in photodynamic inactivation.

\section{Discussion}

In photodynamic inactivation $\mathrm{D}_{2} \mathrm{O}$ was known to lengthen the life time of singlet oxyen (Merkel et al. 1972) and azide ion was known as a specific quencher of singlet oxygen (Nilsson and Kearns 1973). Using the azide ion and deuterated medium, Ito and Kobayashi (1974) and Kobayashi and Ito (1976) proved the participation of singlet oxygen in the photodynamic inactivation of yeast cells sensitized with AO. Furthermore Weishaupt et al. (1976) reported that singlet oxygen was identified as the cytotoxic agent which was probably responsible for in vitro inactivation of TA-3 mouse mammary carcinoma cells following incorporation of hematoporphyrin and exposure to red light. They showed the cytotoxicity of the singlet oxygen using 1, 3-diphenylisobenzofuran as a quencher of photoinactivation of TA-3 cells. In the present experiments, the results of the enhancing effect of $\mathrm{D}_{2} \mathrm{O}$ and the protective effect of $\mathrm{NaN}_{3}$ indicated the participation of singlet oxygen in the photodynamic inactivation of MGH-U1 cells.

In the present study, the dose of argon laser was so low that there was no inactivation of $\mathrm{MGH}-\mathrm{Ul}$ cells. By staining with $\mathrm{AO}\left(1.75 \times 10^{-5} \mathrm{M}\right)$ followed by argon laser irradiation for $1.5 \mathrm{~min}$, only $37 \%$ of the cells survived, showing a remarkable cytocydal effect. The present results show that argon laser at the low intensity and with short irradiation time had a sufficient cytocydal effect suggesting the clinical usefulness of photodynamic inactivation of argon laser with topical use of AO.

A flexible fiberoptic system (Dwyer et al. 1975) can be used to deliver visible laser light to the exposure site, which is a definitive advantage over gamma and 
beta rays. In the treatment of bladder tumor, it is advantageous if the urinary bladder is irradiated with a transurethral endoscope.

Systemic use of AO should be avoided due to its toxicity (Van Duuren et al. 1969), but a method of intravesical instillation may be employed in the treatment of bladder tumor. Although transurethral surgery is at present the most effective method in treating superficial bladder tumors, there are a number of problems in treating high stage tumors, recurrent tumors and, in particular, carcinoma in situ (Melamed et al. 1964 ; Barlebo et al. 1972). In views of the pathologic aspect of carcinoma in situ whereby the epithelial cells do not penetrate the basement membrane, we believe photo-inactivation laser therapy promises to be an effective treatment of carcinoma in situ.

\section{References}

1) Barlebo, H., Sфrensen, B.L. \& Ohlsen, S. (1972) Carcinoma in situ of the urinary bladder. Scand. J. Urol. Nephro., 6, 213-223.

2) Dougherty, T.J., Kaufman, J.E., Goldfarb, A., Weishaupt, K.R., Boyle, D. \& Mittleman, A. (1978) Photoradiation therapy for the treatment of malignant tumors. Cancer Res., 38, 2628-2635.

3) Dwyer, R.M., Haverback, B.J., Bass, M. \& Cherlow, J. (1975) Laser-induced hemostasis in the canine stomach. Use of a flexible fiberoptic delivery system. J. Amer. med. Ass., 231, 486-489.

4) Ito, T. \& Kobayashi, K. (1974) In vivo evidence for the participation of singlet excited oxygen molecules in the photodynamic inactivation. Sci. Pap. Coll. Gen. Educ. Univ. Tokyo, 24, 33-36.

5) Kato, T., Irwin, R.J., Jr. \& Prout, G.R., Jr. (1977) Cell cycles in two cell lines of human bladder carcinoma. Tohoku J. exp. Med., 121, 157-164.

6) Kato, T., Ishikawa, K., Nemoto, R., Senoo, A.\& Amano, Y. (1978) Morphological characterization of two established cell lines, T24 and MGH-U1, derived from human urinary bladder carcinoma. Tohoku J. exp. Med., 124, 339-349.

7) Kelly, J.F., Snell, M.E. \& Berenbaum, M.C. (1975) Photodynamic destruction of human bladder carcinoma. Brit. J. Cancer, 31, 237-244.

8) Kobayashi, K. \& Ito, T. (1976) Further in vivo studies on the participation of singlet oxygen in the photodynamic inactivation and induction of genetic changes in Saccharomyces cerevisiae. Photochem. Photobiol., 23, 21-28.

9) Lewis, M.R. \& Goland, P.P. (1948) In vivo staining and retardation of tumors in mice by acridine compounds. $J$. med. Sci., 215, 282-289.

10) Melamed, M.R., Vousta, N.G. \& Grabstald, H. (1964) Natural history and clinical behavior of in situ carcinoma of the human urinary bladder. Cancer, 17, 1533-1545.

11) Merkel, P.B., Nilsson, R. \& Kearns, D.R. (1972) Deuterium effects on singlet oxygen lifetimes in solutions. A new test of singlet oxygen reactions. J. Amer. chem. Soc., 94, 1030-1031.

12) Nilsson, R. \& Kearns, D.R. (1973) A remarkable deuetrium effect on the rate of photosensitized oxidation of alcohol dehydrogenase and trypsin. Photochem. Photobiol., 17, 65-68.

13) Tomson, S.H., Emmett, E.A. \& Fox, S.H. (1974) Photodestruction of mouse epithelial tumors after oral acridine orange and argon laser. Cancer Res., 34, 3124-3127.

14) Van Duuren, B.L., Sivak, A., Katz, C. \& Melchionne, S. (1969) Tumorigenicity of acridine orange. Brit. J. Cancer., 23, 587-590.

15) Weishaupt, K.R., Gomer, C.J. \& Dougherty, T.J. (1976) Identification of singlet 
oxygen as the cytotoxic agent in photo-inactivation of a murine tumor. Cancer Res., 36, 2326-2329. 